\title{
Etiology of organ-specific autoimmunity: Basic research and clinical implications in IBD
}

\section{GEORGE S EISENBARTH MD PhD}

GS EISENBARTH. Etiology of organ-specific autoimmunity: Basic research and clinical implications in IBD. Can J Gastroenterol 1996;10(2):121-125. Autoimmunity develops in the setting of genetic susceptibility and can be monogenic (eg, autoimmune polyendocrine syndrome type I with Addison's disease, mucocutaneous candidiasis and hypoparathyroidism, which is autosomal recessive with the causative gene on the tip of chromosome 21) or polygenic (usually with important alleles within the major histocompatibility complex [eg, type I diabetes]). In addition to genetic susceptibility, many autoimmune disorders can be classified into etiological categories (oncogenic, drug-induced, diet-induced, infectious or idiopathic). For most autoimmune disorders there are multiple target autoantigens and, for type I diabetes, a combinatorial approach (eg, expression of at least two autoantibodies of insulin, glutamic acid decarboxylase and/or ICA512/IA-2) is the best predictor of diabetes risk. Finally, antigen-specific therapies hold promise for the prevention and therapy of autoimmunity, eg, parenteral or oral therapy with insulin delays or prevents type I diabetes in animal models, and a small pilot trial of parenteral insulin in humans suggests that such therapy may similarly prevent diabetes in humans.

Key Words: Autoantibodies, Combinatorial, Polyglandular failure, Type I diabetes
Étiologie de l'auto-immunité spécifique à un organe : recherche fondamentale et implications cliniques dans les MII

RÉSUMÉ : L'auto-immunité s'installe dans le contexte d'une sensibilité génétique et peut être monogène (par exemple, syndrome auto-immun polyendocrinien de type I avec maladie d'Addison, candidose mucocutanée et hypoparathyroïdisme transmis selon un mode récessif autosomique et dont le gène causal se trouve sur l'extrémité du chromosome 21) ou polygénique (habituellement avec d'importants allèles à l'extérieur du complexe majeur d'histocompatibilité [par exemple, diabète de type I]). En plus d'une susceptibilité génétique, plusieurs troubles auto-immuns peuvent être classés selon des catégories étiologiques (oncogènes, induits par les médicaments ou l'alimentation, infectieux ou idiopathiques). Pour la plupart des maladies auto-immunes, il y a plusieurs auto-antigènes cibles et pour le diabète de type I, l'approche associative (par exemple expression d'au moins deux auto-anticorps de l'insuline, décarboxylase de l'acide glutamique et/ou ICA512/IA-2) est le meilleur facteur de prévisibilité du risque de diabète. Finalement, des traitements spécifiques aux antigènes semblent prometteurs pour la prévention et le traitement de l'auto-immunité, notamment le traitement parentéral ou oral à l'aide d'insuline retarde ou prévient le diabète de type I dans des modèles animaux et un petit essai pilote sur l'insuline administrée par voie parentérale chez l'humain suggère qu'un tel traitement puisse également prévenir le diabète chez l'humain.

Barbara Davis Center for Childhood Diabetes, University of Colorado Health Sciences Center, Denver, Colorado, USA

Correspondence and reprints: Dr GS Eisenbarth, Barbara Davis Center for Childhood Diabetes, University of Colorado Health Sciences Center, 4200 East 9th Avenue, Box B140, Denver, CO 80262, USA. Telephone 303-270-4891, fax 303-270-4892, e-mail george.eisenbarth@uchsc.edu

This paper was presented at the Basic Research and Clinical Implications in IBD meeting, April 6 to 9, 1994, held in Victoria, British Columbia. This paper has also been published in Sutherland LR, et al, eds. Inflammatory Bowel Disease: Basic Research, Clinical Implications and Trends in Therapy. Boston, Dordrecht and London: Kluwer Academic Publishers, 1994 
undamental questions concerning autoimmune disor-
ders include:

- What genetic elements determine disease susceptibility?

- What activates/suppresses autoimmunity in genetically susceptible individuals?

- What are the target autoantigens (initiating, perpetuating, secondary)?

- What are the effector mechanisms?

- What are the clinical sequelae of answers to the above questions in terms of disease prevention with, in particular, antigen-specific therapies?

Answers to these questions are available in humans and spontaneous autoimmune animal models for a subset of the above questions in a subset of autoimmune disorders. For no disease are answers to all questions available. Nevertheless, the clear answers available for a few disorders will almost certainly be relevant to many autoimmune diseases. The linking of autoimmune disorders into characteristic disease syndromes affecting many target tissues provides evidence for the interrelatedness of disease pathogenesis. In particular, the polyendocrine autoimmune syndromes $(1-3)$ indicate that disease susceptibility can lead to multiple organ-specific autoimmune diseases (Table 1) $(5,6)$. In this report, selected organ-specific autoimmune diseases and syndromes with specific answers to the above questions will be reviewed with an emphasis on type I diabetes.

\section{GENETIC ELEMENTS}

For most (but not all) organ-specific autoimmune syndromes, genes within the major histocompatibility complex (MHC) contribute to susceptibility (4). An interesting exception is the polyendocrine autoimmune syndrome type I, with its associated mucocutaneous candidiasis, Addison's disease and hypoparathyroidism. This syndrome is inherited in an autosomal recessive manner. In contrast to Addison's disease of the type II autoimmune polyendocrine syndrome (APS), which is strongly associated with DR3 and DR4 haplotypes, the type I syndrome with Addison's disease has no class II human leukocyte antigen (HLA) association (7). In addition, approximately $5 \%$ of individuals with this syndrome develop type I diabetes. The DQ molecule DQA $1 * 0102$,DQB1*0602 is usually dramatically protective for type I diabetes $(8,9)$. This molecule occurs in approximately $20 \%$ of Caucasians, but among approximately 250 patients with type I diabetes, we have observed only one individual with this allele, and that individual has APS type I. DQA1*0102,DQB1*0602 is associated with protection from type I diabetes even in the presence of cytoplasmic islet cell autoantibodies. Approximately $12 \%$ of islet cell autoantibody-positive first-degree relatives of patients with type I diabetes express this allele, but we have yet to observe one such relative progress to diabetes. One hypothesis is that protection by this class II allele requires an active immune response and this response cannot be generated in the pres-
TABLE 1

Autoimmune polyendocrine syndromes

\begin{tabular}{ll}
\hline Type I syndrome & Type II syndrome \\
\hline $\begin{array}{l}\text { Mucocutaneous candidiasis } \\
\text { Hypoparathyroidism }\end{array}$ & \\
$\begin{array}{l}\text { Addison's disease } \\
\text { Type I diabetes (5\%) }\end{array}$ & Addison's disease \\
Chronic active hepatitis & Type I diabetes (50\%) \\
Graves' disease/thyroiditis & Graves' disease/thyroiditis \\
Vitiligo & Vitiligo \\
Asplenism & Celiac disease \\
& Serositis \\
Pernicious anemia & Pernicious anemia \\
& Stiff-man syndrome/ \\
& Parkinson's disease \\
& Myasthenia gravis \\
IgA deficiency* & IgA deficiency \\
\hline
\end{tabular}

${ }^{*}$ See reference 5 ; ${ }^{\dagger}$ See reference 6 . Ig Immunoglobulin

ence of the immunodeficiency associated with APS type I. DQA $1 * 0102$,DQB1*0602 does not protect from all autoimmunity; for example, this molecule is associated with multiple sclerosis. Protection from diabetes by class II alleles is most dramatically demonstrated by transgenic nonobese diabetic (NOD) mice, in which replacement of the missing functional DRalpha allele (I-E alpha of mouse) protects from diabetes. The mechanism underlying this protection is unknown.

The insulin autoimmune syndrome is characterized by high levels of insulin autoantibodies and is almost always associated with methimazole therapy for Graves' disease. Essentially $100 \%$ of individuals with this syndrome are DR4positive with the specific DRB1*0406 allele (10). In patients developing type I diabetes, lower levels of anti-insulin autoantibodies are usually present, and in this case the autoantibodies are associated with lineage 1 DQalpha alleles $\left(01^{*}\right.$ to 04*) (11). In particular, DR3 homozygous prediabetic and islet cell autoantibody-positive individuals homozygous for DQA1*0501 rarely express anti-insulin autoantibodies.

Celiac disease is of particular interest in that the disorder appears to be associated with a specific DQalpha and DQbeta heterodimer (DQA1*0501,DQB1*0201), produced either in trans with DR5 (DQA1*0501,DQB1*0301) and DR7 (DQA1*0201,DQB1*0201) or cis with DR3 (DQA1*0501,DQB1*0201) containing haplotypes (4).

Finally, myasthenia gravis is associated with different HLA haplotypes depending upon disease initiating factors. Idiopathic myasthenia gravis is associated with DR3, while myasthenia gravis developing after ingestion of penicillamine is associated with DR7 (12).

Class II alleles within the MHC have received the most attention relative to disease pathogenesis. Because these molecules are essential for antigen presentation, this emphasis is likely to be appropriate. Nevertheless, with more than 100 genes within this region and extensive linkage disequi- 
librium between alleles, other genes important for immunological function may contribute to disease susceptibility (13-15).

Besides identifying genes within the MHC, intense efforts are underway to identify other loci contributing to disease susceptibility. Most of these efforts have not been successful or confirmed, including intense study of $\mathrm{T}$ cell receptor genes. For type I diabetes, polymorphisms of the insulin gene are clearly associated with risk of type I diabetes $(16,17)$. In addition, several repositories have DNA and Epstein-Barr virus lines available from hundreds of families with type I diabetes. With the availability of appropriate family resources and polymorphic microsatellite markers spanning the human genome, it is very likely that additional important loci will be identified. We hypothesize that such loci, similar to mutations of the fas (apoptosis) gene in lpr mice (18), will globally influence ability to maintain tolerance and prevent autoimmunity. In association with such 'global' autoimmune genes, it is likely that alleles within the MHC contribute to targeting specific organs.

\section{DISEASE ACTIVATION}

Factors that trigger autoimmunity have been elegantly defined for a small number of autoimmune disorders such that an etiological classification of autoimmunity can be proposed (Table 2). It is noteworthy that for several forms of oncogenic autoimmunity, specific molecules are expressed only by the tumours associated with the remote autoimmunity (19-23). Several of these triggering molecules have been identified and sequenced (24). The existence of oncogenic autoimmunity suggests that presentation of selfantigens within inflammatory lesions can abrogate selftolerance. It is clear from experimentally induced autoimmune disorders that immunization with self-antigens (2527) and self-peptides can lead to autoimmunity and tissue destruction. Thus, lymphocytes reacting with self-antigens are present in normal animals.

The ability to 'break tolerance' to a series of molecules within inflammatory lesions may also contribute to the existence of linked autoimmune disorders such as Graves' thyroid disease associated with Graves' ophthalmopathy, and ovarian autoimmunity associated with myasthenia gravis. A recent report demonstrates that $T$ cells recognize relatively few amino acids within peptides (27). Thus, $\mathrm{T}$ cell lines can react with peptides of both the acetylcholine receptor and $\mathrm{ZP} 3$, the ovarian sperm receptor sharing fewer than five of nine amino acids. Thus immunization with the appropriate peptide of the acetylcholine receptor can induce ovarian destruction (27).

Studies of type I diabetes have failed to identify a crucial environmental factor triggering type I diabetes. The three factors receiving the majority of study include congenital rubella infection (28), Coxsackie viral infection (29) and ingestion of milk within the first three months of life (30).

Congenital rubella infection is associated with a marked increase in diabetes risk. One hypothesis relates a $52 \mathrm{kDa}$ islet protein recognized by diabetic sera (with homology to

\section{TABLE 2}

\section{Etiological classification of autoimmunity}

\begin{tabular}{ll}
\hline Etiology & Disease - Trigger \\
\hline Oncogenic & Cerebellar degeneration - ovarian cancer \\
Drug-induced & Myasthenia gravis - penicillamine \\
Diet-induced & Celiac disease - gluten \\
Infectious & Rheumatic fever - streptococci \\
Idiopathic & Type I diabetes - unknown \\
\hline
\end{tabular}

heat shock protein 60) to a specific rubella capsid protein (31). The rubella and islet protein are both recognized by an antirubella monoclonal antibody. Rubella infection increases the risk of diabetes only with fetal infection. Thus an alternative hypothesis is that rubella infection increases the risk of diabetes secondary to lifelong $\mathrm{T}$ cell abnormalities (32). These $T$ cell abnormalities may also contribute to the frequent occurrence of thyroiditis in such patients.

Coxsackie viral infections were originally associated with type I diabetes when it was assumed that the disorder was of acute onset. With accumulating data supporting that type I diabetes develops slowly in the majority of individuals, it is likely that acute infections at disease onset are not of direct pathogenic significance. Recently one of the most studied autoantigens associated with type I diabetes, glutamic acid decarboxylase (GAD) (33-36), was found to have homology with a peptide sequence of a Coxsackie protein. This region of homology is being studied for relevance to disease induction.

A large number of epidemiological studies suggests that either decreased breast-feeding or early introduction of cow's milk products increases diabetes risk (37-40). These epidemiological data are surprisingly consistent given the less than twofold increased risk. The risk ascribed to cow's milk ingestion may be higher in individuals with genetic susceptibility to type I diabetes. Trials to test the elimination of cow's milk from diets of infants are being designed. One hypothesis relating cow's milk to type I diabetes is that bovine albumin shares several small regions of homology with an islet molecule termed ICA69 or p69. Pietropaolo and co-workers (43) recently cloned, sequenced and expressed ICA69. Although there is considerable controversy over whether antibodies to albumin are associated with type I diabetes, several laboratories have now demonstrated that ICA69 autoantibodies are present in more than $50 \%$ of individuals developing type I diabetes $(41,42)$ and in fewer than $5 \%$ of normal controls (43). A number of studies are now addressing $\mathrm{T}$ cell responses to albumin and ICA69.

\section{AUTOANTIGENS}

During the past several years investigators have characterized a large series of islet autoantigens. Similar to other organ-specific autoimmune disorders (44), islet enzymes are prominent islet autoantigens. Autoantigens include GAD (45), carboxypeptidase H (46) and a novel tyrosine phosphatase termed ICA512. In addition, the hormone insulin (47-51) and ICA69 (52) (unknown function) are recognized 
by autoantibodies and T cells. Gangliosides, and in particular a GM2-1 islet ganglioside (53), are also recognized by anti-islet autoantibodies.

With an increasing number of islet autoantigens, whether any given autoantigen is primary to the disease process and whether any given autoantigen is primary for any individual developing type I diabetes are unanswered questions. I favour the hypothesis that if there is a primary autoantigen it will be insulin. Insulin is the only beta cell-specific target molecule. All other characterized autoantigens are expressed in nonislet cells (particularly neuroendocrine cells) or within the alpha and delta cells of islets, which are not destroyed in patients with type I diabetes. For example, GAD in the rat is beta cell-specific, but in humans GAD is expressed by non-beta cells (36).

Criteria to distinguish primary from 'secondary' autoantigens are being developed. The most important evidence that insulin plays an important role in the pathogenesis of type I diabetes comes from studies of insulin reactive $T$ cell clones and therapy of NOD mice and humans with insulin. $T$ cell clones that react with an insulin peptide have recently been isolated from NOD islets (personal communication). T cells reacting with a peptide of the $B$ chain of insulin are a major component of intra-islet $\mathrm{T}$ cells; most important, such $\mathrm{T}$ cells are capable of transferring diabetes to NOD severe combined immunodeficiency disease mice, which are unable to generate B and T lymphocytes. Insulin

\section{REFERENCES}

1. Muir A, Maclaren NK. Autoimmune diseases of the adrenal glands, parathyroid glands, gonads, and hypothalamic-pituitary axis. Endocrinol Metab Clin North Am 1991;20:619-44.

2. Riley WJ. Autoimmune polyglandular syndromes. Horm Res 1992;38(Suppl 2):9-15.

3. Eisenbarth GS, Jackson RA. The immunoendocrinopathy syndromes. In: Wilson JD, Foster DW, eds. Williams Textbook of Endocrinology, 8th ed. Philadelphia: WB Saunders Company, 1992:1555-66.

4. Nepom GT, Erlich H. MHC class-II molecules and autoimmunity. Ann Rev Immunol 1991;9:493-525.

5. Garty BZ, Kauli R. Alopecia universalis in autoimmune polyglandular syndrome type I. West J Med 1990;152:76-7. (Lett)

6. Torrelo A, Espana A, Balsa J, Ledo A. Vitiligo and polyglandular autoimmune syndrome with selective IgA deficiency. Int J Dermatol 1992;31:343-4.

7. Maclaren NK, Riley WJ. Inherited susceptibility to autoimmune Addison's disease is linked to human leukocyte antigens DR3 and/or DR4, except when associated with type I autoimmune polyglandular syndrome. J Clin Endocrinol Metab 1986;62:455-9.

8. Baisch JM, Weeks T, Giles R, Hoover M, Stastny P, Capra JD. Analysis of HLA-DQ genotypes and susceptibility in insulin-dependent diabetes mellitus. N Engl J Med 1990;322:1836-41

9. Erlich HA, Griffith RL, Bugawan TL, Ziegler R, Alper C, Eisenbarth GS. Implication of specific DQB1 alleles in genetic susceptibility and resistance by identification of IDDM siblings with novel HLA-DQB1 allele and unusual DR2 and DR1 haplotypes. Diabetes 1991;40:478-81

10. Uchigata Y, Kuwata S, Tsushima T, et al. Patients with Graves' disease who developed insulin autoimmune syndrome (hirata disease) possess HLA-Bw62/Cw4/DR4 carrying DRB1*0406. J Clin Endocrinol Metab 1993; 77:249-54.

11. Pugliese A, Bugawan T, Moromisato R, et al. Two subsets of HLA-DQA1 alleles mark phenotypic variation in levels of insulin autoantibodies in first degree relatives at risk for insulin-dependent diabetes. J Clin Invest 1994;93:2447-52.

12. Garlepp MJ, Dawkins RL, Christiansen FT. HLA antigens and reactive $\mathrm{T}$ cells are both present in the islet lesion of $\mathrm{NOD}$ mice and capable of producing beta cell destruction and type I diabetes (personal communication). In my studies and those of Ziegler et al (50) of the chronology of autoimmunity in humans, insulin autoantibodies frequently precede autoantibodies to other autoantigens, including GAD. Oral ingestion of insulin can delay or prevent diabetes in NOD mice (54), and pilot studies suggest that parenteral insulin administration may prevent type I diabetes in a subset of islet cell autoantibody-positive first-degree relatives of patients with type I diabetes (55). This pilot trial has been followed by a large multicentre National Institutes of Health trial for the prevention of type I diabetes with parenteral insulin therapy.

With a series of characterized autoantigens, and identification of susceptibility, alleles and two spontaneous animal models, studies of the pathogenesis of type I diabetes are accelerating. It is hoped that with increased knowledge, type I diabetes mellitus will be preventable and the lessons learned for this illness will have a positive impact on studies of other autoimmune disorders.

ACKNOWLEDGEMENTS: Supported by grants from the National Institutes of Health (DK32083, DK43279), the Juvenile Diabetes Foundation, the American Diabetes Association, the Blum-Kovler Foundation and the Children's Diabetes Foundation. The Children's Hospital CRC was essential for the clinical studies described.

acetylcholine receptor antibodies in penicillamine induced myasthenia gravis. BMJ 1983;286:338-40.

13. Awdeh ZL, Raum D, Yunis EJ, Alper CA. Extended

HLA/complement allele haplotypes: evidence for T/t like complex in man. Proc Natl Acad Sci USA 1983;80:259-63.

14. French MAH, Dawkins RL. Central MHC genes, IgA deficiency and autoimmune disease. Immunol Today 1990;11:271-4.

15. Li X, Golden J, Faustman DL. Faulty major histocompatibility complex class II I-E expression is associated with autoimmunity in diverse strains of mice. Diabetes 1993;42:1166-72.

16. Julier C, Hyer RN, Davies J, et al. Insulin-IGF2 region encodes a gene implicated in HLA-DR4-dependent diabetes susceptibility. Nature 1991;354:155-9.

17. Lucassen A, Julier C, Beressi J-P, et al. Susceptibility to insulin dependent diabetes mellitus maps to a $4.1 \mathrm{~kb}$ segment of DNA spanning the insulin gene and associated VNTR. Nature Genetics 1993;4:305-10.

18. Watanabe-Fukunaga R, Brannan CI, Copeland NG, Jenkins NA, Nagata S. Lymphoproliferation disorder in mice explained by defects in Fas antigen that mediate apoptosis. Nature 1992;356:314-7.

19. Anhalt GJ, SooChan K, Stanley JR, et al. Paraneoplastic pemphigus. An autoimmune mucocutaneous disease associated with neoplasia. N Engl J Med 1990;323:1729-35.

20. Hetzel DJ, Stanhope R, O’Neill BP, Lennon VA. Gynecologic cancer in patients with subacute cerebellar degeneration predicted by anti-Purkinje cell antibodies and limited in metastatic volume. Mayo Clin Proc 1990;65:1558-63.

21. Kornguth SE. Neuronal proteins and paraneoplastic syndromes. N Engl J Med 1989;321:1607-8.

22. Grunwald GB, Simmonds MA, Klein R, Kornguth SE. Autoimmune basis for visual paraneoplastic syndrome in patients with small-cell lung carcinoma. Lancet 1985;i:658-61.

23. Anhalt GJ, SooChan K, Stanley JR, et al. Paraneoplastic pemphigus: An autoimmune mucocutaneous disease associated with neoplasia. N Engl J Med 1990;323:1729-35.

24. Dropcho EJ, Chen Y-T, Posner JB, Old LJ. Cloning of a brain protein identified by autoantibodies from a patient with paraneoplastic cerebellar degeneration. Proc Natl Acad Sci USA 1987;84:4552-6. 
25. Massacesi L, Joshi N, Lee-Parritz D, Rombos A, Letvin NL, Hauser SL. Experimental allergic encephalomyelitis in cynomolgus monkeys: Quantitation of T cell responses in peripheral blood. J Clin Invest 1992;90:399-404.

26. Rhim SH, Millar SE, Robey F, et al. Autoimmune disease of the ovary induced by a ZP3 peptide from the mouse zona pellucida. J Clin Invest 1992;89:28-35.

27. Luo A-M, Garza KM, Hunt D, Tung KSK. Antigen mimicry in autoimmune disease sharing of amino acid residues critical for pathogenic T cell activation. J Clin Invest 1993;92:2117-23.

28. Ginsberg-Fellner F, Witt ME, Yagihashi S, et al. Congenital rubella syndrome as a model for type I (insulin-dependent) diabetes mellitus: increased prevalence of islet cell surface antibodies. Diabetologia 1984;27:87-9.

29. Frisk G, Friman G, Tuvemo T, Fohlman J, Diderholm H. Coxsackie B virus IgM in children at onset of type I (insulin-dependent) diabetes mellitus: evidence for IgM induction by a recent or current infection. Diabetologia 1992;35:249-53.

30. Kostraba JN, Cruickshanks KJ, Lawler-Heavner J, et al. Early exposure to cow's milk and solid foods in infancy, genetic predisposition and risk of IDDM. Diabetes 1993;42:288-95.

31. Karounos DG, Wolinsky JS, Thomas JW. Monoclonal antibody to rubella virus capsid protein recognizes a B-cell antigen. J Immunol 1993;150:3080-5.

32. Rabinowe SL, George KL, Laughlin R, Soeldner JS, Eisenbarth GS. Congenital rubella: monoclonal antibody defined $\mathrm{T}$ cell abnormalities in young children. Am J Med 1986;81:779-82.

33. Atkinson MA, Kaufman DL, Campbell L, et al. Response of peripheral-blood mononuclear cells to glutamate decarboxylase in insulin-dependent diabetes. Lancet 1992;339:458-9.

34. Kaufman DL, Erlander MG, Clare-Salzler M, Atkinson MA, Maclaren NK, Tobin AJ. Autoimmunity to two forms of glutamate decarboxylase in insulin dependent diabetes mellitus. J Clin Invest 1992;89:283-92.

35. Rowley MJ, Mackay IR, Chen Q, Knowles WJ, Zimmet PZ. Antibodies to glutamic acid decarboxylase discriminate major types of diabetes mellitus. Diabetes 1992;41:548-51.

36. Petersen JS, Russel S, Marshall MO, et al. Differential expression of glutamic acid decarboxylase in rat and human islets. Diabetes 1993;42:484-95

37. Martin JM, Trink B, Daneman D, Dosch H, Robinson B. Milk proteins in the etiology of insulin-dependent diabetes mellitus (IDDM). Ann Med 1991;23:447-52.

38. Borch-Johnson K, Joner G, Mandrup-Poulsen T, et al. Relation between breast-feeding and incidence rates of insulin-dependent diabetes mellitus. Lancet 1984;ii:1083-6.

39. Vialettes B, Zevaco-Mattel C, Thirion X, et al. Acute insulin response to glucose and glucagon in subjects at risk of developing type I diabetes. Diabetes Care 1993;16:973-7.
40. Gerstein HC. Cow's milk exposure and type I diabetes mellitus. Diabetes Care 1994;17:13-9.

41. Pietropaolo M, Castano L, Babu S, Powers A, Eisenbarth GS. Molecular cloning and characterization of a novel neuroendocrine autoantigen (PM-1) related to type I diabetes. Diabetes 1992;41 (Suppl 1):98A. (Abst)

42. Karjalainen J, Martin JM, Knip M, et al. A bovine albumin peptide as a possible trigger of insulin-dependent diabetes mellitus. N Engl J Med 1992;327:302-7.

43. Handwerger S, Capel WD. Differences in the cell surface antigens of prolactin-producing cells of human decidual and pituitary tissues. J Clin Endocrinol Metab 1985;61:830-3.

44. Winqvist O, Gustafsson J, Rorsman F, Karlsson FA, Kampe O. Two different cytochrome P450 enzymes are the adrenal antigens in autoimmune polyendocrine syndrome type I and Addison's disease. J Clin Invest 1993;92:2377-85.

45. Baekkeskov S, Aanstoot H, Christgau S, et al. Identification of the $64 \mathrm{~K}$ autoantigen in insulin dependent diabetes as the GABA-synthesizing enzyme glutamic acid decarboxylase. Nature 1990;347:151-6.

46. Castano L, Russo E, Zhou L, Lipes MA, Eisenbarth GS. Identification and cloning of a granule autoantigen (carboxypeptidase $\mathrm{H}$ ) associated with type I diabetes. J Clin Endocrinol Metab 1991;73:1197-201.

47. Palmer JP, Asplin CM, Clemons P, et al. Insulin antibodies in insulin-dependent diabetics before insulin treatment. Science 1983;222:1337-9.

48. Vardi P, Ziegler AG, Matthews JH, et al. Concentration of insulin autoantibodies at onset of Type I diabetes: inverse log-linear correlation with age. Diabetes Care 1988;11:736-9.

49. Ziegler AG, Ziegler R, Vardi P, Jackson RA, Soeldner JS, Eisenbarth GS. Life table analysis of progression to diabetes of anti-insulin autoantibody-positive relatives of individuals with type I diabetes. Diabetes 1989;38:1320-5.

50. Ziegler AG, Hillebrand B, Rabl W, et al. On the appearance of islet associated autoimmunity in offspring of diabetic mothers: a prospective study from birth. Diabetologia 1993;36:402-8.

51. Castano L, Ziegler A, Ziegler R, Shoelson S, Eisenbarth GS. Characterization of insulin autoantibodies in relatives of patients with insulin-dependent diabetes mellitus. Diabetes 1993;42:1202-9.

52. Zielasek J, Jackson RA, Eisenbarth GS. The potentially simple mathematics of type I diabetes. Clin Immunol Immunopathol 1989;52:347-65.

53. Dotta F, Previti M, Tiberti C, Lenti L, Pugliese G, DiMario U. Identification of the GM2-1 islet ganglioside: Similarities with a major neuronal autoantigen. Diabetes 1992;41:365A.

54. Zhang JZ, Davidson L, Eisenbarth GS, Weiner HL. Suppression of diabetes in nonobese diabetic mice by oral administration of porcine insulin. Proc Natl Acad Sci USA 1991;88:10252-6.

55. Keller RJ, Eisenbarth GS, Jackson RA. Insulin prophylaxis in individuals at high risk of type I diabetes. Lancet 1993;341:927-8. 


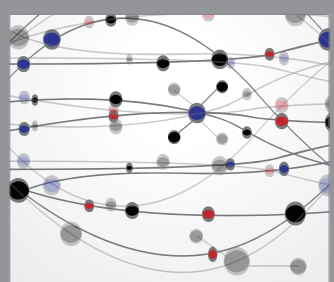

The Scientific World Journal
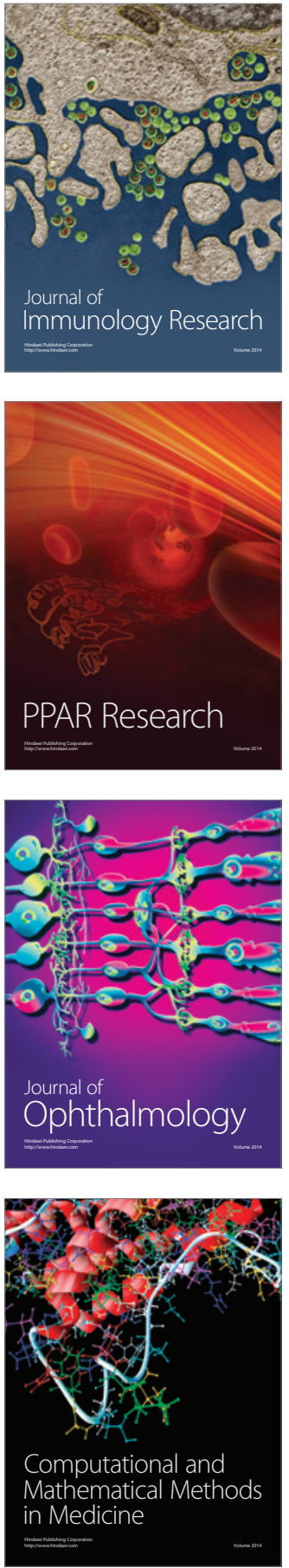

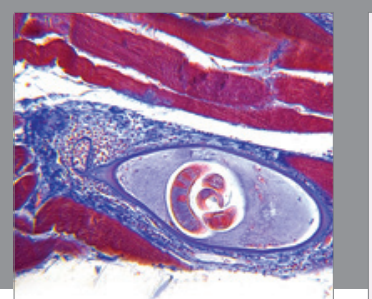

Gastroenterology Research and Practice

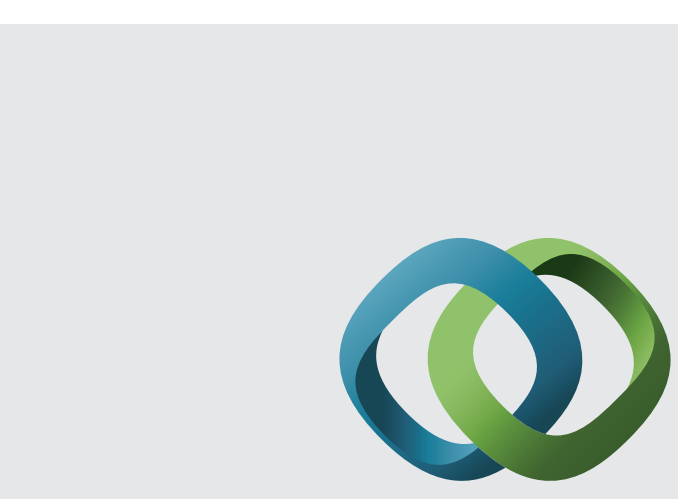

\section{Hindawi}

Submit your manuscripts at

http://www.hindawi.com
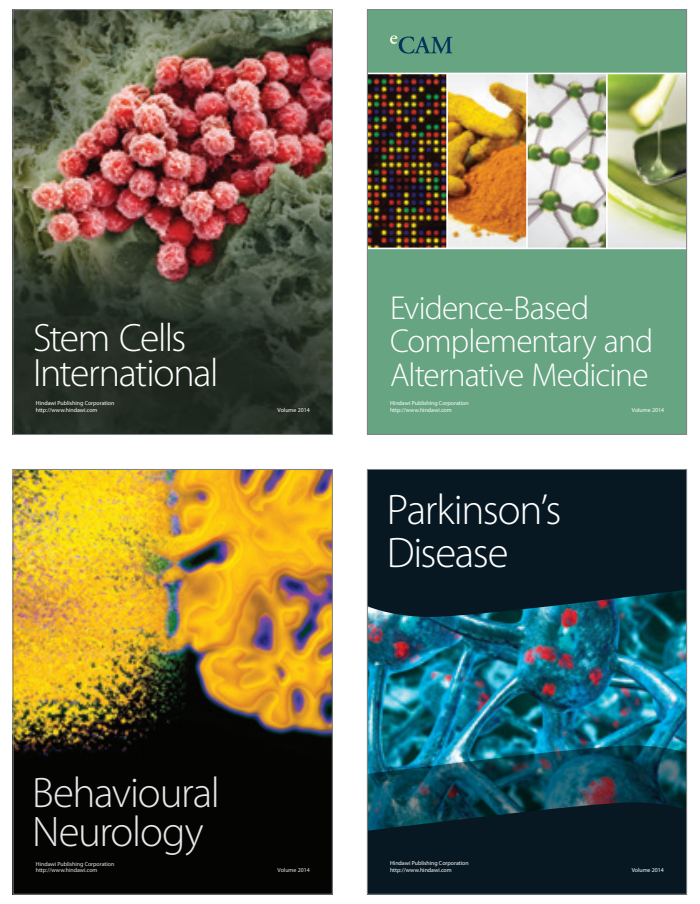
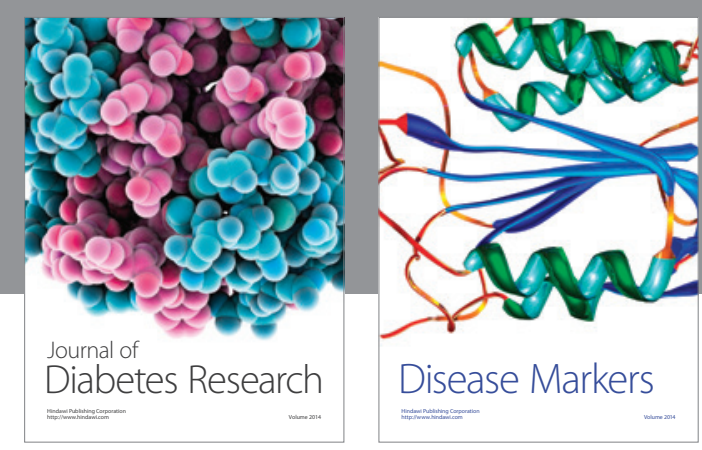

Disease Markers
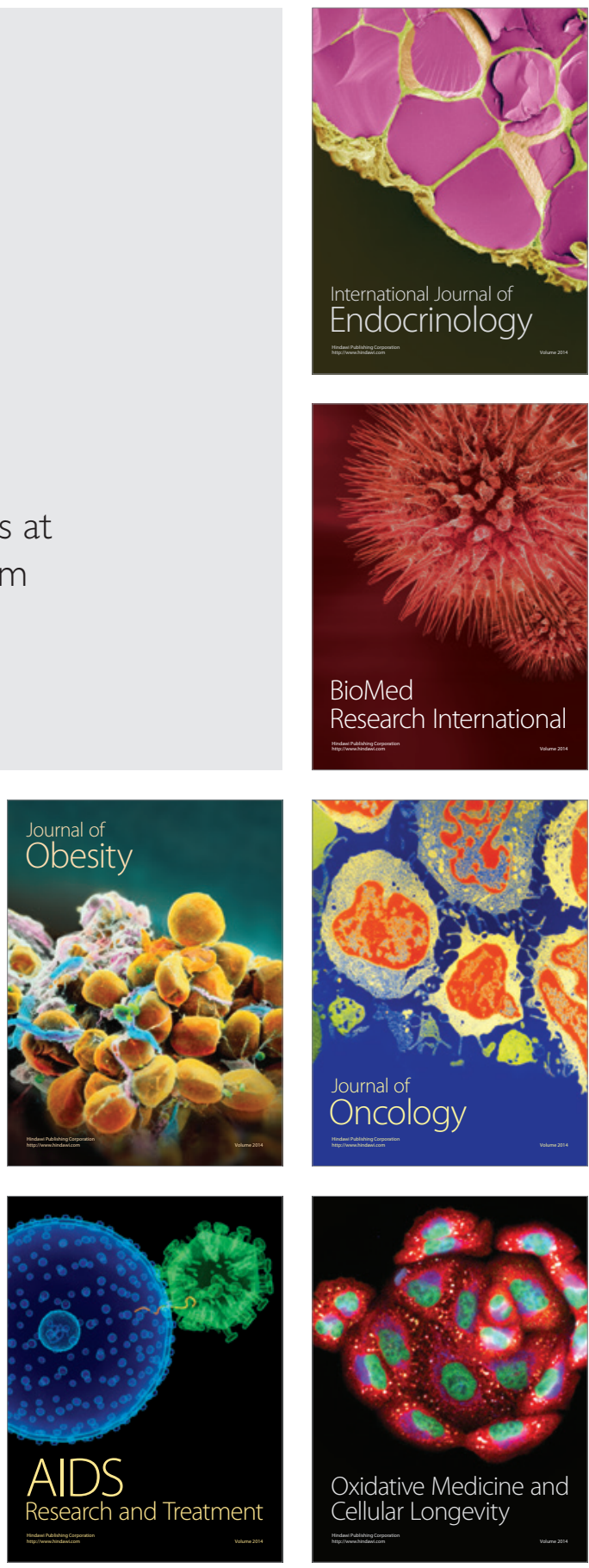